\title{
University of Shanghai Cooperation Organization Serves for "the Belt and Road" Initiative: SWOT Analysis and Strategy Choice
}

\author{
Jiao Zeng, * \\ ${ }^{1}$ Guangdong University of Foreign Studies South China Business College, Guangzhou, Guangdong 510545, \\ China \\ *Corresponding author. Email: zengjiao1234@163.com
}

\begin{abstract}
The University of Shanghai Cooperation Organization was born in the framework of Shanghai Cooperation Organization. From the beginning of its establishment, it has undertaken its own mission under the guidance of "Shanghai spirit". After more than ten years of development, the platform has become more and more mature, with a relatively perfect legal basis, a stable and orderly organizational framework, a characteristic "2 +2 " working mechanism, and a relatively perfect joint talent training system; But at the same time, it also faces some problems, such as lack of endogenous power, slow scale expansion, inadequate external publicity and so on. Against the background of "the Belt and Road" Initiative construction and SCO expansion, USCO should take the "community with a shared future for mankind" as the value coordinate and carry out educational cooperation and exchange with equal and win-win situation. In order to enhance its influence and service, it is necessary to expand the scale of running schools according to the regional international market demand; In order to promote the sustainable development of the University, it will be a must to change the top-down government led mode and move towards the multi linkage mode of the combination of the top and the bottom.
\end{abstract}

Keywords: "The Belt and Road" Initiative(B\&R), University of Shanghai Cooperation Organization University(USCO), Shanghai Cooperation Organization(SCO), Community with a shared future for mankind.

\section{INTRODUCTION}

Shanghai Cooperation Organization (SCO) was born on June 15th, 2001. Its initial members are China, Russia, Kazakhstan, Kyrgyzstan, Tajikistan and Uzbekistan. It is the first regional international organization established in Eurasia after entering the 21 st century. It is also the first international organization named after a Chinese city and headquartered in China. The core values it advocates and practices are the "Shanghai spirit" of "mutual trust, mutual benefit, equality, consultation, respect for diversity and culture, and pursuit of common development". This is a new concept beyond the cold war thinking, which creates a new regional cooperation model in Eurasia and makes an innovative exploration for the

*Sponsors: Guangzhou philosophy and Social Sciences Planning Project in 2019. Approval No. : 2019GZQN44. establishment of a fair and reasonable new international political and economic order. [1] Since "the Belt and Road" Initiative(B\&R) was put forward in 2013, it has been mentioned in the meetings speeches of the Council of SCO members' heads. ${ }^{1}$ It is not difficult to see that the relationship between the two is very close. "B\&R" Initiative focuses on building "five links". Education can not only directly promote people to people communication, but also provide talent resources and intellectual support for other "four links".

1. The meeting of heads of State Council of SCO member states is held once a year. The seven speech of President Xi Jinping here is from thirteenth meetings in 2013 to 2019. Details can be found here: https://www.fmprc.gov.cn/web/gjhdq_676201/gjhdqzz_681964/1 hg_683094/zyjh_683104/default.shtml. 
Under the guidance of "Shanghai spirit", University of Shanghai Cooperation Organization University(USCO) pursues five goals and tasks, [2] It is a long-term, stable and comprehensive platform for educational cooperation and exchange based on strategic purposes. After the expansion in 2017, SCO has become an important platform for the construction of "B\&R" Initiative, endowed with the interconnection function beyond security cooperation, and become an international organization of cross regional governance. [3] The Qingdao summit in 2018 has opened a new era for SCO to connect with "B\&R" Initiative. Under the background of "B\&R" Initiative", what kind of opportunities and challenges USCO, which has been developing for more than ten years, is facing? And how to make full use of the "soft power" of education?

In this paper, SWOT analysis is used to analyze the opportunities and challenges faced, there are four aspects: strengths (S), weaknesses (W), opportunities (O) and threats (T). It is helpful for USCO to give full play to favorable factors, avoid unfavorable factors, and put forward coping strategies for USCO under the background of "B\&R" Initiative".

\section{AN ANALYSIS OF THE INTERNAL ADVANTAGES OF USCO SERVING "THE BELT AND ROAD" INITIATIVE}

\subsection{The Legal Basis Is Relatively Perfect}

The effective operation of USCO depends on both the invisible hand of trust and the visible hand of law. The laws such as "Agreement on education cooperation among the governments of SCO member states", "Letter of intent of the Ministry of education of the SCO member states on further concerted action for the establishment of the USCO "and "Memorandum of cooperation on the establishment of USCO", have set up a basic legal framework for the educational cooperation of SCO and the establishment of USCO. "The Charter of USCO", "Attachment to the certificate of academic qualifications of USCO", "Measures for the coordination of joint training programs for Postgraduates", and other documents signed in succession. They provide necessary legal support and guarantee for the stable and orderly operation of USCO.

\subsection{The Organizational Structure Is Stable and Orderly}

There are four permanent bodies of USCO: the Coordination Committee, the supervisory committee, the president's Office (Secretariat) of USCO and the expert committee of each training direction. The Coordination Committee is responsible for coordinating the liaison work between USCO and national education authorities and relevant institutions; The supervisory committee is committed to sorting out the good image of USCO in the education sector of member countries and countries all over the world, absorbing funds, attracting business institutions to participate in the joint training of talents, and assisting graduates in employment; The president's office is mainly responsible for ensuring teaching, scientific research and daily management; The purpose of the expert committee is to assist in the teaching and scientific research of various training directions. In addition, the "Secretariat of USCO China's internal coordination mechanism" has been set up to provide relevant information analysis for the Secretariat and project institutions, organize and hold a working meeting of Chinese project institutions in various professional directions once a year, cooperate with foreign cooperation project institutions and education departments, and only implement USCO diploma and graduation certificate. After years of development, the abovementioned institutions have formed a stable and orderly management system.

\subsection{A Multi-level Working Mechanism Has Been Set up}

USCO has set up a characteristic " $2+2 "$ working mechanism, namely the official meeting of Ministers of education and the meeting mechanism of standing expert working group, the nongovernmental "education without borders" education week and the University Presidents Forum. Since its first session in October 2006, the conference of Ministers of education has been held every two years, taking turns among Member States. It mainly discusses major cooperation issues, such as the list of projects, the docking of education systems in member countries, and the direction of cooperation, so as to reach a consensus and make clear the direction for the development of education cooperation at each stage. The standing expert working group is a standing official executive body responsible for formulating specific text programs and implementing action measures. 
"Education without borders" education week is a dialogue and coordination platform for cooperation in the field of education. It holds an annual meeting to enhance mutual understanding, carry out academic exchanges, and promote the implementation of project plans and lists. The University Presidents Forum is a negotiation platform for university presidents under the framework of "education without borders" education week. The topics focus on the planning, activity organization and implementation of each academic year of Shanghai University of cooperation. It puts forward feasible suggestions on the operation and development of USCO, and discusses the next work arrangement. [1]

\subsection{Continuous Improvement of Talent Training System}

At present, there are 82 colleges and Universities under the cooperation program of USCO, with 7 professional directions, namely, regionalism, ecology, energy, information technology, nanotechnology, economics and education. By linking up the education systems of various countries, and studying and formulating the training specialty, teaching mode, educational system and curriculum, USCO has formed a unified teaching space. Students who enter the relevant majors of domestic project colleges become project students and are included in the USCO personnel training system. USCO joint personnel training starts from the master's level, and then extends to undergraduate and doctor. Now, it has formed an integrated talent training system.

\section{AN ANALYSIS OF THE INTERNAL WEAKNESS OF USCO SERVING "THE BELT AND ROAD" INITIATIVE}

\subsection{Insufficient Endogenous Power}

Theoretically speaking, when the participating institutions choose partners according to their own needs, their internal motivation is the strongest. However, USCO is initiated from top to bottom under the SCO framework, so the expected benefits of member universities are not the same, and there are also some passive project universities. According to official information, USCO has 82 project universities, but only 75 universities are more or less actively involved in the project, [4] Especially, no university in Uzbekistan has joined
USCO, so far, which shows its lack of motivation. In addition, foreign students tend to choose to receive education in Europe, the United States and others, resulting in the imbalance of student flow in USCO. In addition, language barriers also affect the enthusiasm of teachers and students. The official languages of SCO are Chinese and Russian, but few teachers and students are proficient in using Chinese in foreign universities; Similarly, apart from Russian Majors, there are not many teachers and students in Chinese universities who are proficient in Russian. Only by Russian Majors enrolling, the source of students is greatly limited; Although some colleges can teach in English, it is necessary to use the local language in the life of studying abroad.

\subsection{The Scale Expansion Is Relatively Slow}

Ten years later, USCO has begun to take shape, but its expansion is relatively slow, which can be seen from the number of Member States, the number of project universities, the direction of cooperative majors and the number of joint training talents. At the beginning of its establishment, there were 62 project universities in five member countries, and up to now, there are 82 project universities in five countries[5]; The number of cooperative majors was 5 before 2012 and increased to 7 in that year, and there was no new major after that. According to the statistics on the official website of USCO (China), since the 20122013 academic year, in the USCO project, there have been 591 Chinese expatriates and 310 foreign students in China, with a total of 901 . The number of students has not changed much in the past five years, and has been maintained at an average of $150 .^{2}$ It is important to strengthen the connotation construction and pay attention to the quality improvement, but the overall scale expansion is slow, which is also a problem worthy of reflection.

\subsection{Imperfect Information Platform Construction}

In the information age, any organization's external publicity and internal and external information exchange cannot do without the network channel. Although the supervisory committee is committed to building up a good

2. In July 2020, the author compiled the data according to the exchange dynamic of Chinese project institutions of USCO. http://www.usco.edu.cn/CHS/ywzx/. 
image of USCO in SCO member countries and the education circles all over the world, it is far from enough. The construction of official information platform of USCO is essential. Statistics show that USCO has neither official micro-blog nor WeChat public address. Only official website has a low update rate of website information. The website of USCO (China) official account, which was launched in May 3, 2020, takes 8 columns. The update time of "University profile" is October 2016, the update time of "news center", "media focus" and "business center" is December 2019, the update time of "project colleges" is May 2014, the update time of enrollment information is June 2017, and the update time of contact information is June 2015. The information content of the website is not rich, and there is no complete document of laws and regulations on the official website. As a window for USCO's external publicity and an important channel for all sectors of the society to understand it, it should bear the responsibility of publicizing the achievements of USCO to the outside world. Transparent, open and timely publicity of information is conducive to enhancing the confidence and trust of Member States and enhancing the attraction and attention of USCO.

\section{AN ANALYSIS OF THE EXTERNAL OPPORTUNITIES OF USCO SERVING "THE BELT AND ROAD" INITIATIVE}

\subsection{The Core Values Come Down in One Continuous Line}

"B\&R" Initiative and SCO all reflect China's governance, development and cooperation. The core values of "B\&R" Initiative are "the spirit of the Silk Road", that is, peaceful cooperation, openness and inclusiveness, mutual learning and mutual benefit; the core values of SCO are "Shanghai spirit", namely "mutual trust, mutual benefit, equality, consultation, respect for diverse civilizations, and seek common development"; They both conform to the two themes of peace and development, that is, seeking common peace and common development. [6] As a platform for educational cooperation within the SCO framework, values of USCO are naturally consistent with those of SCO. Therefore, the core values of the two organizations are interlinked, which is conducive to the continuity of USCO's goals and tasks in the process of "B\&R" Initiative docking, not forgetting the original intention, but also pioneering and enterprising.

\subsection{It Is Concerned by the Government and the Education Department}

Compared with other international union of universities established under "B\&R" initiative, from its establishment to its operation, USCO has been highly valued by the leaders of governments and education departments. The initiative for the establishment of USCO was proposed by Russian President Vladimir Putin during the SCO Bishkek summit. The specific implementation plan was jointly studied by the ministries of education of all countries, and finally deliberated by the Committee of heads of government of SCO member states. In just two years, USCO was formally established and put into operation. Within five years, the institutional framework was initially established. With the promotion of many annual meetings of various levels of mechanism, the convergence of education system, training mode and academic certification has made rapid progress. In addition, the Chinese government has been providing scholarships for the foreign derivative of the USCO program and students coming to China. Kazakhstan also has a Polsak Program to encourage students to study abroad. In terms of policy support and financial support, USCO has inherent advantages in docking development.

\subsection{The Vast Space Brings Great Potential}

The accession of India and Pakistan has extended the geographical scope of SCO member states to South Asia, with a total area of nearly 34.4 million square kilometers, accounting for $70 \%$ of the Eurasian continent; The total population increased to 3.13 billion, accounting for $44 \%$ of the world's total population; The total GDP exceeds 15 trillion US dollars, accounting for one fifth of the global GDP, and the trade volume accounts for one third of the global GDP. [7] SCO countries are located along "B\&R", covering four important economic corridors of "B\&R", namely "ChinaMongolia-Russia", "new Eurasian land bridge", "China-Central Asia-West Asia" and "ChinaPakistan Economic Corridor". The "B\&R" initiative is not an entity organization and mechanism for China's self-interest. It is more cooperative, open, non-exclusive and win-win, meeting the common needs of SCO countries. This will bring new blood and new impetus to SCO economic cooperation. The increase of multilateral economic and trade 
cooperation will inevitably increase the demand for international talents, and the function of education serving the economy will be highlighted.

\subsection{Being in Line with the Development Trend of Education Internationalization}

The global flow of higher education resources and the bilateral or multilateral development of educational exchanges and cooperation are the trend of the times. Whether it is the education cooperation between countries in the region or the education interaction between countries across continents, there have been many years of practice. All countries have realized that to play a better role in higher education, we must break the boundaries between countries and conduct cross-border exchanges and interaction. With the development of internationalization of higher education, many countries are looking for ways to develop their own higher education, trying to enhance their own higher education strength through education cooperation, and cultivate more international talents to serve their own regional development. Therefore, the development of USCO meets the needs of the internationalization of higher education in various countries.

\section{AN ANALYSIS OF THE EXTERNAL THREATS OF USCO SERVING "THE BELT AND ROAD" INITIATIVE}

\subsection{Distrust of the Internal and External Conservative Forces}

Although SCO announced from the very beginning that it was not a military bloc and did not target any country, its core values and organizational principles also showed its peace, the United States and other western conservative forces have always looked at the SCO with tinted glasses, Especially with the continuous development and growth of SCO, some Western politicians with cold war thinking regard it as "non Western political power", and they have no reason to suspect and guard against some will and behavior of SCO. [8], After the "B\&R" initiative was put forward, some western countries have a narrow understanding of it. They either regard it as the revival of the ancient Silk Road, or just regard it as an infrastructure project, lacking a deep understanding of the "five links"; Other countries worry that it does not meet the existing standards and rules, that it will damage their own interests and shake the international system. [9] At the same time, there are different degrees of differences and contradictions among SCO members. After the expansion of SCO members, the dual engine pattern of China and Russia is facing challenges, which may form a tripartite confrontation among China, Russia and India, and the difficulty of "consensus" among SCO members is further increased; Moreover, the Indian government often stands on the same front with western countries on major international issues. It has a negative attitude towards China's "B\&R" initiative and is wary of the relationship between China and Pakistan. [10] Misunderstandings, doubts, prejudices from the outside and distrust from some internal members may adversely affect the development of SCO and USCO.

\subsection{The Level of Educational Development Varies Greatly Among Countries}

SCO involves 18 countries. The differences in economic size, cultural tradition, education level, religious belief and other aspects affect the in-depth promotion of regional education exchange and cooperation. Among them, the uneven level of education has the most direct impact. According to the existing research statistics, there are great differences in the gross enrollment rate of higher education in SCO countries. Turkey, Belarus, Russia, Iran and Mongolia have the highest gross enrollment rate of higher education, all of which are more than 60\%; The lowest are Pakistan, Uzbekistan, Afghanistan, Cambodia, Nepal and other countries, all less than $20 \%$. Their higher education is still in the stage of elite education or just entering the stage of popularization; The gross enrollment rate of higher education in other countries is between $20 \%$ and $50 \%$. [11] The world university rankings reflect the higher education level of a country or region. In the USnews 2020 world university rankings, only 20 universities in SCO region, including 18 universities in China (including 5 universities in Hong Kong and 1 University in Taiwan), 1 University in Russia and 1 University in Turkey, are in the top 300; In the QS2020 world university ranking, only 24 universities in China (including 6 universities in Hong Kong and 6 universities in Taiwan), 5 universities in Russia and 6 universities in India, with a total of 35 universities in the top 300; Only 15 universities in China (including 5 in Hong Kong, 1 in Taiwan and 1 in Macao) and 3 universities in Russia, with a total of 18 universities, have entered 
the top 300 in the 2020 world university rankings. ${ }^{3}$ It can be seen that the development of domestic higher education in SCO is extremely uneven, which will objectively lead to the challenge of inconsistent enthusiasm and driving force of various countries when USCO develops in depth.

\subsection{The Influence of European Union on Education in Central Asia}

"EU and Central Asia: new partnership strategy" holds that "the majority of the population in Central Asia is under 25 years old, which makes the region have great development potential". [12] With a view to building the future of Central Asia in mind, the EU's assistance to the five Central Asian countries in the field of higher education over the years has attached equal importance to energy and security. Although the EU has promoted the transformation and modernization of higher education in Central Asian countries through the implementation of Tempus(TEMPUS), its potential motivation is to realize its own interests. It actively promotes the popularization of "European credit transfer system", "Bologna principle", "academic quality certification system" and "academic quality management system" in Central Asian countries. It is based on the European education system to reform the higher education system of Central Asian countries, and then produces "knowledge driving force" for the development of Central Asian countries, So as to comprehensively enhance the EU's influence on Central Asia. [13] In other words, more than 20 years of education aid is not only an important way for the EU to influence and shape the Central Asian countries, but also a main tool to realize the export of values and benefit sharing. [14] The impact of EU education on the education of Central Asian countries is bound to cause interference and disadvantage to the further development of USCO.
3. In July 2020, the author compiled it according to the official website data of USnews, QS and THE.website : https://www.usnews.com/education/best-globaluniversities/rankings; https://www.topuniversities.com/qs-worlduniversity-

rankings; https://www.timeshighereducation.com/worlduniversity-rankings.

\section{THE STRATEGY CHOICE OF USCO SERVING "THE BELT AND ROAD" INITIATIVE}

\subsection{Taking the "Community of Shared Human Destiny" as the Value Coordinate, It Is Necessary to Achieve Equality and Win-Win Results and Safeguard the Common Interests of the Region}

First of all, "community with a shared future for mankind" is in the common interest of education in all countries. In the 2015 annual meeting of the Boao forum for Asia, President Xi Jinping explained the four connotations of moving towards "community with a shared future for mankind": insisting on mutual respect and equal treatment; Adhere to win-win cooperation and common development; Adhere to common, comprehensive, cooperative and sustainable security; adhere to the principle of inclusiveness, exchange and mutual learning among different civilizations. [15] The idea of "community with a shared future for mankind" is in the same line with "Shanghai spirit" and "Silk Road spirit", but it is not the product of natural development. In the construction of "community with a shared future for mankind", the establishment of a just and equal new international political and economic order, education should bear the due responsibility and responsibility. It is in the common interest of SCO countries to lead the development of USCO with the concept of "community with a shared future for mankind" and build an equal and win-win international education cooperation platform.

Secondly, the "center edge" structure in international educational cooperation and exchange should be eliminated. In the process of shaping the world into a "center-periphery" structure, higher education is naturally woven into the "theory of superiority of civilization" concocted by the West. In the first and second developing countries, the world higher education pattern of "center country leading, edge country controlled" has been formed. Some late developing countries rely on the norms and standards of the central countries in the construction of higher education system. It seems that they have to turn to the famous universities in developed countries and cooperate with them to provide legitimacy for their academic behavior, which to some extent strengthens the "dependence pattern" and even a "recolonization" process. [16] Fortunately, the ancient civilization began to return 
to the new generation. The "return" means that the diversity of civilization is presented again, and the relationship between civilizations is equal again. [17] The concept of diversity and equality is one of the connotations of "community with a shared future for mankind", USCo should always stick to its original intention, carry out educational cooperation and exchange on the basis of equality and win-win results, change the "center periphery" educational hegemony mode, and change the SCO countries' dependence on Europe and America in educational system, theory and system.

\subsection{To Meet the Needs of the International Market, It Is Necessary to Expand the Scale and Enhance the Influence and Service of Shanghai Cooperation University}

Under the "community with a shared future for mankind" initiative, USCO should be guided by the "international market demand" in SCO region and adjust its development strategy appropriately to enhance its service. First of all, USCO should expand its radiation scope as soon as possible. At least all SCO member countries have universities to join the alliance. When the time is right, universities from observer countries and dialogue partner countries can also be considered. Over the past ten years, educational exchanges and cooperation among the first five countries have not matched the development speed of SCO.

Secondly, increase the number of priority cooperative majors. As of April 2020, USCo's priority areas of cooperation are limited to regionalism, ecology, energy, it technology, nanotechnology, economics and education. With the expansion of SCO and the proposal of "B\&R" initiative, the training of talents in only seven majors has been unable to meet the talent demand of various fields in the regional international market.

Thirdly, personnel training should be extended to higher vocational level. Since "B\&R" initiative was put forward, Chinese enterprises have been going out on a large scale, but they are deeply troubled by the lack of human resources. They urgently need a large number of technical talents who have feelings for China, understand Chinese culture, and are familiar with Chinese equipment and technical standards. [18] USCO should respond to the development of regional economy, investigate the talents needed for the construction of "B\&R" + SCO, bring higher vocational and technical education into its framework, jointly cultivate technical and skilled talents at higher vocational level, and provide more communication and cooperation platforms for Vocational Education in various countries.

\subsection{With the Combination of Top and Bottom, It Is Necessary to Promote the Sustainable Development of USCO from Government Leading to Multi Linkage}

Firstly, it is of great significance to change from the top-down mode to the combination mode.

Educational diplomacy should serve the national interests. Even if the implementer of educational diplomacy is a non-state actor, the state actor is also the narrator behind it. [19] In the promotion of "B\&R", under the premise of ensuring the top-down guidance of the central government and the national education department, we should constantly strengthen the top-down construction force, mobilize local governments, enterprises, scientific research institutions, non-governmental organizations and other non-governmental theories to participate in the construction of the University.

Secondly, it is a must to give full play to the comparative advantages of various regions.

At present, there are eight Chinese project universities in the eastern region, one in the central region, four in the western region, and seven in the northeast region; The universities in the eastern region are mainly concentrated in Beijing, while those in the western region are mainly concentrated in Urumqi and Lanzhou. This distribution has a lot to do with geographical location and cultural tradition, However, some scholars believe that the cooperation between China and Russia is too concentrated in Northeast China, Beijing and Shandong, which is not conducive to the pragmatic development of universities and the real implementation of the agreement. [20] No universities in Yunnan, Guangxi, Sichuan and Chongqing in the western region, and Guangdong, Jiangsu and Zhejiang in the eastern region have entered the USCO platform, In terms of geography and higher education development level, we should rethink the regional layout of project colleges. 


\section{CONCLUSION}

It has become a fact that the pattern of world intercultural relations is developing in the direction of diversification, which may result in two trends, [21] One is the trend of "competition conflict" represented by Huntington's "civilization conflict theory"; the other is the trend of "mutual integration and mutual learning" represented by "community with a shared future for mankind" advocated by China. Obviously, the latter is positive and ideal, and is an important driving force to promote world progress, but the prediction of the first view has also been partially verified. How to avoid cultural conflicts, and truly realize mutual integration and mutual learning, people's hearts and minds are interlinked, people are the most important factor. It is people who decide the trend of intercultural relations, so whether it is SCO or "B\&R", People to people and cultural exchanges are crucial links. USCO is an important platform for members of different cultural bodies to carry out international education cooperation and exchange. The more significant changes in world cultural relations occur, the more efforts should be made to strengthen cooperation and exchange. Only by broadening the channels of cooperation and exchange, constantly strengthening consensus and building identity can we lead human beings to mutual integration and mutual learning, and promote the world towards pluralistic symbiosis Positive and cooperative intercultural relations.

\section{AUTHORS' CONTRIBUTIONS} Zeng.

This paper is independently completed by Jiao

\section{REFERENCES}

[1] National Research Center of Shanghai Cooperation Organization, China. Shanghai Cooperation Organization: Retrospect and prospect (2001-2018). Beijing: World Knowledge Press, 2018, pp.3. (in Chinese)

[2] Brief introduction to USCO. http://www.usco.edu.cn/CHS/dxjj/. [accessed 15 April 2020].(in Chinese)

[3] Wang Yiwei. SCO + "the Belt and Road". http://www.xinhuanet.com/globe/201806/19/c_137264410.htm. [accessed 17 April 2020].(in Chinese)
[4] USCo opens up new cooperation and offers special Diploma. http://www.cankaoxiaoxi.com/china/2015020 9/659316.shtml. [accessed 20 April 2020].(in Chinese)

[5] USCO: a private ambassador to build a heart Bridge.

http://www.usco.edu.cn/CHS/mtjj/20170612/4 32.htm.[accessed 15 May 2020].(in Chinese)

[6] Li Zi Guo. The relationship between "the Belt and Road" and SCO [J]. Russian Journal, 2019,9 (05): 85-99. (in Chinese)

[7] Liu Huaqin. The idea of deepening SCO regional economic cooperation $[\mathrm{J}]$. Russia, Eastern Europe and Central Asia research, 2014 (01): 31-37. (in Chinese)

[8] Zhao Mingwen. Shanghai Cooperation Organization and China's Western security. China's peripheral security environment assessment and policy options, Beijing: World Knowledge Press, 2015, pp.391. (in Chinese)

[9] In the face of Western doubts, "the Belt and Road" clarifies misunderstanding with facts. http://m.haiwainet.cn/middle/3543393/2018/0 313/content_31276970_1.html.[accessed 15 April 2020]. (in Chinese)

[10] Han Lu. Deepening the economic cooperation of the Shanghai Cooperation Organization: opportunities, obstacles and Directions [J]. Research on international issues, 2018 (03): 56-68. (in Chinese)

[11] Liu Zhimin, Zhu yichai. The development of "the Belt and Road" university strategic alliance from the perspective of Value Philosophy [J]. University education management, 2020, 14 (01): 16-28. (in Chinese)

[12] "The EU and Central Asia: Strategy for a New Partnership", pp.8. http://delkaz.ec.euopa.eu

[13] Liu Jiye. EU assistance to higher education projects in Central Asia [J]. International information, 2010 (03): 24-28 (in Chinese)

[14] Xu Gang. Evolution, characteristics and trends of EU's Central Asia Policy [J]. Journal of Russian Studies, 2016,6 (02): 17-28 (in Chinese)

[15] Xi Jinping explains the four connotations of moving towards "community with a shared 
future for mankind". http://politics.people.com.cn/n/2015/0328/c70 731-26764211.html. [accessed 25 May 2020]. (in Chinese)

[16] Zhou Zuoyu, Ma Jiani. community with a shared future for mankind value coordinates of international cooperation in Higher Education [J]. Education research, 2017,38 (12): 42-50. (in Chinese)

[17] Qian Chengdan. The diversity of civilization and the future of modernization [J]. Journal of Peking University (philosophy and social sciences), 2016,53 (01): 8-12. (in Chinese)

[18] Zhai fan. Enterprises "going out", looking forward to vocational colleges to catch up, perspective the opportunities and challenges of Vocational Education under the "community with a shared future for mankind" initiative [N]. China Education Daily, 17 August 2015 (03) (in Chinese)

[19] Antonio F. de Lima Jr. The Role of International Educational Exchanges in Public Diplomacy [J]. Place Branding and Public Diplomacy, 2007, (3): 234-251.

[20] Liu Shuhua, song Yonghua. Higher education cooperation between China and Russia under the background of "a": Problems and countermeasures [J]. Higher education research, 2019,40 (04): 96-103.(in Chinese)

[21] Qin Yaqing. The relationship between the century change and new culture $[\mathrm{J}]$. World knowledge, 2020 (01): 25-27.(in Chinese) 